\title{
Deltheden hos Grundtvig efter 1832
}

\author{
Af Jorgen Elbek
}

I en lille bog "Grundtvigs atten prøveår" har jeg skrevet om udviklingen fra hans åndelige opvågnen i 1805 til den frugtbare sommer 1824. "Fra Nyårsmorgen til Nordens Mytologi ", et tillæg til bogen, som er trykt i Kritik nr. 31, omhandler de syv magre år som fulgte. På de følgende sider beskæftiger jeg mig med Grundtvig efter 1832, men begrænser mig til et træk hvorved han adskiller sig fra sine tidligere aldre, som jeg har skildret dem. Når jeg siger 1832, undgår jeg ikke at bringe Kaj Thanings skrifter $\mathrm{i}$ erindring, men går af hensyn til pladsen ikke $\mathrm{i}$ debat med dem.

\section{Helt og skjald}

Ved en helt forstår Grundtvig en mand, som vil mere end dagen og vejen. Sådan en helt var Christoffer Columbus som søgte paradisets have, men fandt den ny verden, og Rasmus Rask, som satte livet til under sit forsøg på at drage de døde sprog frem i lyset - se mindedigtene om dem fra 1831 og 1832. "Overalt hvor jeg erkender en kraftig stræben som går ud over det dyriske jordliv, agter jeg den, hvor underlig den så end ytrer sig “ skrev Grundtvig som ung, netop med henblik på Rask. Helten drives, med Jakob Knudsens udtryk, af "vildfarende idealitet".

Men ved heltens side står skjalden, som drømmer om den højhed, helten søger efter. Helten leverer stof til skjaldens digt $\mathrm{i}$ kraft af sin dåd, og skjalden sørger gennem sit digt for heltens eftermæle, hans jordiske udødelighed, som bliver det faktiske resultat af hans himmelsøgen. Helt og skjald er nødvendige for hinanden og bunder til syvende og sidst i det samme, nemlig 
det som ligger ud over dagen og vejen og altså træder splittet frem i verden som den er.

Grundtvig placerer sig på den ene side af skellet og gør sig til skjalden - se digtet "Til kristne venner " fra 1833. Her fortæller han også, ligesom i afsnittet om høstgildet i indledningen til "Nordens Mytologi", hvad der er det personlige grundlag for hans nye stilling: Skabt ikke til at blomstre i sommerens sol, men til at bære frugt om høsten træder han nu ind i sin rette alder; men den henter sin fylde fra en tid, der aldrig har været hans:

Derfor ej som skjald jeg skælver

for den kolde, dunkle tid:

Dejligst blå sig buen hvælver over bøgetoppen hvid...

og i Norden

der har natten mer end skygger, vinter en højrøstet fugl, i hvis toner sammensmelte fortids år med deres helte.

Skønt altid ener, som skjald finder Grundtvig på plads i historien. I de samtidshistoriske foredrag "Mands minde" (1838) siger han at hans var altid skjaldens lykke og han ser sig - som Sophus Claussen hundrede år senere - som en af dem "der ringede et nyt århundred ind ". Mindedigtene over Povl Dons, Thorvaldsen og Kamma Rahbek på Bakkehuset (1843-45) er fælles om at fejre morgenkoret af kunstnere, som vågnede efter slaget i 1801. Digtene bliver til i kraft af en "sommerdag i efteråret, ungdomsrus i alderdom" som der står i det sidste af dem.

\section{Folk og historie}

"I historien kan talen lige så lidt være om som for de umælende" skriver Grundtvig dybt inde i Universalhistorien (1833-43) og mener dermed at det folk som gør sig kraftigt gældende i verdensudviklingen, det får af sig selv sine historieskrivere, mens 
folk, der kun findes skildret af deres fjender, de har selv været ude om det. Udviklingen går mod et mål, som ligger, hvor Grundtvig selv er og lader sit lys trænge tilbage gennem tider og lande, men rigtigt folde sig ud skal det først $\mathrm{i}$ fremtiden, når oplysningen er blevet almindelig. Uanset hvad fortidens mennesker selv kan have haft i sinde, så er det hvad virkning de har haft for lysets vækst der giver dem deres plads i historien: Josefs brødre solgte ham, fordi de ville ham til livs, men selv siger han til dem ved gensynet: "I tænkte ondt imod mig, men Gud tænkte at vende det til det gode ". ${ }^{1}$ Den ånd, der besjæler historiens folk, er ikke deres hensigter, men det mål, de virker for, og ånden ytrer sig dobbelt, som i skikkelsesparret feltherren Belisar og historikeren Prokopios, der begge måtte have "en langt høiere og ædlere tænkemåde end resten for at have både sind og evne til deres udmærkede dåd".

I forholdet til folkene er Grundtvig selvsagt historikeren, ligesom han i forhold til helten var skjalden.

\section{Ungdom og oplysning}

Oplysningen, som Grundtvig venter og arbejder på skal komme, ligner han ved solskin og stiller han i modsætning til lynild. Det hedder i digtet Gyldenåret (1834), at i højskolens dage:

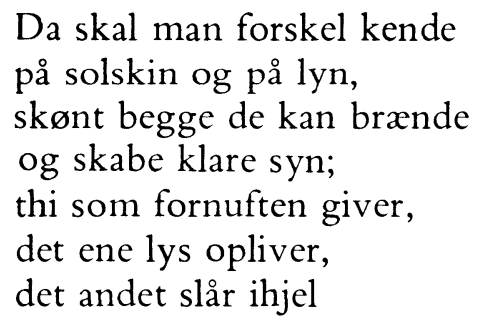

Men den oplysning, som han kender af egen erfaring, er kommet som et lyn, for så vidt den er kommet udefra. Ordet er nok en sol, der skinner i lys og løn, som der står i Friskolesangen (1841), men det slår ned som et lyn ligesom englen der nedfarer og vælter stenen fra graven. Henrik Steffens er i mindedigtet (1845) lynildsmanden og Clare Boltons kulsorte øje har samme lynende virkning som i sin tid Steffens' ord (Småfruerne, 1844). Hovedsagen i hans oplysningsprogram er, at det lys, som er 
blevet ham selv til del i hans lange liv, det skal også blive andres. Men det er tanken, at for de andre skal det komme udefra, meddelt gennem det levende ord, til trods for at selv er han blevet klog af skade - et ordsprog som han gerne anfører - og først med årene har han samlet forstand. Som grundlag for oplysningen, der skal komme ad en anden vej, end den efter sit væsen kan - solskin slår jo ikke ned som lyn - lægger han to emnekredse, som hans egen udvikling har knyttet sig til, nemlig de nordiske myter, som han fik sit liv i efter 1805, og det danske sprog som kom til ham gennem barndomstidens salmer under krisen $1810 .{ }^{3}$ De skal gøre det ud for "Nordens ånd og Danmarks hjerte«, for han slår på vognen, men mener hestene.

Tilsvarende er højskoleundervisningens formål at meddele "ingenlunde alt hvad vi ved, men alt hvad deraf til gavn og glæde kan være facllesgods", vi skal "med flid stræbe hos os selv at adskille hvad der kun tilhører os som enkeltmend... fra hvad vi kan have tilfalles med folket" (Bøn og begreb, 1840). Hvad kan være fælles? Alt hvad der har været vigtigt for Grundtvig selv i hans udvikling, og som samtidig har virkelighed for andre. Samfundsbåndet skal knyttes mellem mennesker med samme modersmål og ikke fx med samme arbejde.

Ligesom historien går mod en stigende grad af oplysning, ligger der i hvert menneske en higen ud af mørket. Det kan nytte noget at undervise, for "alle levende mennesker har lyst til at blive så kloge og oplyste som muligt " (tale på Marielyst 1856). Men er så han et levende menneske som ikke længere søger sig egen oplysning, men vil påføre ungdommen en, der er en spejling af udenværkerne til den, han har haft?

\section{Naturalist og kristen}

I "Nordens mytologi«, hvor højskoletanken første gang fremsættes, er det et hovedpunkt, at folk af forskellig tro kan samarbejde, blot de har samme ånd, d.v.s. det gør ikke noget at de venter hver sit af deres indsats, hvis ellers de stiler mod samme mål. Den ånd eller målsætning, der kan gøre sig gældende hos os, har udtrykt sig i de gamle myter og ytrer sig altid som en kamp for udødelighed. Her kæmper "skolen for livet " med, og kristen og ikke-kristen (naturalist) må kunne stå sammen og det på lige fod. 
Men kan de nu det? Som kristen ved Grundtvig, at egentlig udødelighed kan man ikke kæmpe sig til, kampens udbytte begrænser sig til eftermælet. De andre tillægger målet for kampen en vægt, som det ikke kan bære, og hvad må den kristne mene om det? Ikke andet end at kun af skade bliver man klog: hvis de får lov at løbe linen ud, vil de mærke den briste, og selve bruddet åbner for en mere omfattende forståelse - menneske først og kristen så - ligesom det nordiske hedenskab i sin tid veg for kristendommen. Man tænker sig bedst naturalisten som den unge og den kristne som mere erfaren, men så er de ikke længere på lige fod, så er de ikke skolen for livets samarbejdende lærere, men lærer og elev. Sådan gik det jo også rent historisk, det blev kirkens folk og kun dem der kom til at stå for højskolen i dens storhedstid.

\section{Helg og søgn}

Kirken ændrer omkring 1832 væsen og går over, samtidig med at Grundtvig bliver prædikant igen, fra at være Herrens historiske indstiftelse til især at blive stedet, hvor han her og nu står op i ordet, når menigheden forsamles. Kirken bliver et ugentligt, håndgribeligt oplevet fællesskab, hvad der deler tiden $\mathrm{i}$ et indenog et udenfor dens mure - "Har vi toppet, må vi dale" siger han i 1845 med henblik på den salighedens forsmag à la forklarelsen på bjerget, som gudstjenesten giver ham.

\section{And og hjerte}

I digtene til sin anden hustru (1851) siger Grundtvig om deres kærlighedsmøde: "Så favner guldhjertet oldtidens ånd og lærer sig selv at forstå ". I og med at han ser sig selv som ånden og kvinden som hjertet, er han på vej til at gøre sig halv. Til gengald beder han hende tage ham "helt og holden", ligesom han tager hende "helt som du er". "Sandelig, Vorherre tager eder som I er " - med de ord byder han menigheden til alters under sindsrystelsen i $1867,{ }^{4}$ som han, mens den står på, opfatter som en nøjagtig gentagelse af anfaldet i $1844 .^{5}$

Da hustruen er død (1854), skriver han: "-der skulle vist også stærkere ben end mine til ret længe at bære så gode dage; thi var jeg ikke allerede bleven uretfærdig mod alt i verden, der ikke var som hun, og treven til alt, hvad der ikke var for hende«? "An- 
faldet i 1867 kalder han bagefter sin dødsstrid, og anfaldet i 1844 et udslag af hedenskab. Hver gang han ville tages for hvad han 'var, blev han klar over at han var blandet.

- Grundtvigs delthed, som her er søgt eftervist inden for hvert af hans hovedområder, ligger inden for dem alle i hans forestilling om egen særart og begrænsning parret med hans ønske om at vekselvirke med, hvad der ligger udenfor.

P.S. Ovenstående er indtryk, der er blevet tilbage efter et semesters øvelser over Grundtvigs oplysningsskrifter, og jeg fremsætter dem her i anledning af Gustav Albecks påstand i forrige årgang: at jeg lagde op til en "massiv nedvurdering" af Grundtvigs senere forfatterskab.

\section{Noter}

1. Tak til William Michelsen for 1 . Mos. $\mathbf{5 0 . 2 0 ~ s o m ~ s a m m e n f a t n i n g ~ a f ~ G r u n d t - ~}$ vigs historiesyn.

2. Min understregning.

3. Se H. Begtrup: Grundtvigs kristelige opvækkelse s. 74 og Grundtvigs kirkelige syn s. 194.

4. Grundtvigs Erindringer og Erindringer om Grundtvig v. Steen Johansen og Henning Høirup s. 247.

5. Sammesteds s. 240 . 